\title{
Marketing as Applied through Publishing: Converting Theory to Practice
}

\section{Annabelle Corrick}

Marketing can be adapted to library practice theoretically and shown graphically by using the marketing tools of product design, pricing, communication, and distribution as they relate to the library production tasks: acquisitions, cataloging, circulation/reference, and to new-materials promotion. Using Philip Kotler's concepts of marketing, new-materials promotion is directed toward the library's publics, and evaluation and planning are used to consistently meet their needs. A popular CA/SDI device, the acquisitions list, serves as an example. The survey technique was used to evaluate the publication described, and a new, more effective format was planned and instituted.

\section{THE MARKETING APPROACH}

Librarians in the 1980 s are experiencing the information explosion, the influx of automated systems, and the retrenchment of budget cutbacks compounded by soaring operating costs. At no time has the tension between our potential capabilities and our limited resources seemed more acute. We are also faced with an irksome "culture lag" in which the general public maintains an antiquated view of librarians, assuming that they still function outside the realm of technological advancement and social science management systems. Library organizations themselves often are fractionalized by "old school" self-images and policies that cling to the limited caretaker approach to librarianship and hold back the progressive efforts of "new school" professionals.

In order to counter the disparity between what we might be able to accomplish and what our budgets will allow us to do, we must focus attention on our funding sources. Stronger support will be forthcoming only if our image improves and our services seem worthwhile. How to achieve this goal is a long-standing issue, and "librarians from time immemorial have tried to interpret their services to their clientele." 1

Only recently, however, have libraries sought to use a systematic marketing approach. With guaranteed funding and a secure place in society, libraries of the past operated with a production orientation like business firms in pre-affluent societies. They assumed that demand for their product would continue forever and customers would always be plentiful. ${ }^{2}$ The library's collection, its card catalog, and its traditional reference and circulation services seemed adequate enough to serve its patrons, and efforts need only be expended on producing these "products."

Even with the advent of more difficult and uncertain times, libraries have usually stopped short of a comprehensive marketing plan. They often adopt a sales approach and propagandize their services without analyzing user needs beforehand or instituting long-range programs. Prod- 
uct satisfaction tends to decrease as the sales pitch increases. Credibility is diminished and users grow distrustful of future messages. ${ }^{4}$

The marketing approach represents a radical change in philosophy because it requires systematic planning and operates on the principle of exchange. Programs are instituted to fulfill user needs. The buyer selects the product that the seller provides without the seller having to use any force or threat mechanism. In business terms, the seller anticipates buyer needs and adapts his products to these needs as they grow, change, or diminish. Major American business firms began to invest in consumer research to measure consumer needs and satisfaction in the mid-1950s. By the 1970 s, a "broadened concept of marketing" evolved among theorists who realized that marketing behavior could function in other situations besides the conventional exchange of goods and services for money. ${ }^{5}$

Philip Kotler, perhaps the leading marketing theorist, recognizes that "the transposition of a conceptual system from one domain (the profit sector) to another (the nonprofit sector) poses a number of challenges that call for a new creative conceptualization. ${ }^{1 / 6}$ It is the purpose of this study to analyze and redefine marketing terms as they relate to library service and to provide an example of a basic library marketing instrument used by the University of Missouri-Kansas City (UMKC) Law Library: a mailing for new-materials promotion called the Acquisitions List.

\section{THE MARKETING MIX}

The philosophical concept behind marketing strategy, that it is based on exchange techniques rather than on threat or force systems, is obviously applicable to nonprofit organizations generally and to libraries in particular. Kotler cites the example of a local police department offering protective services in exchange for tax monies and cooperation from citizens. He also points out that churches offer members religious services and experiences in exchange for cooperation and support. ${ }^{7}$ Like other nonprofit organizations, libraries are already in existence because they fulfill a need for the community or educational institution. Libraries even have some advantage over corporations trying to promote products of little intrinsic worth.

It is the adaptation of marketing tools that requires redefinition and creative conceptualization. The marketing toolsproduct design, pricing, communication, and distribution work together in a "marketing mix."' Communication alone cannot sell a product. An article of clothing, for example, must be the style and quality as advertised, it must be tagged for the right price and size, it must be in the right store with sales consultants to identify it and explain it to the customer, and the store must have cashiers to conduct the sale. The production tasks must back up and fulfill the communications message. When the mix is successful and all units of the organization place user needs in top priority, the result is integrated marketing. ${ }^{10}$

Each of the marketing tools correlates with a library system. A design department of a fashion merchandising business will plan a new line or adaptation of suit coats; an acquisitions department of a library will make collection development plans and select new books and materials accordingly. Commercial articles are priced and tagged for sale; books and serials are cataloged, and classification labels are put on each item. Products for actual sale are distributed to stores and put on their appropriate racks with salespersons to assist them; books are put on shelves in libraries with circulation and reference personnel to help users find what they need and to check out the materials.

These production tasks are established parts of business procedures, and they have traditionally been a part of libraries. The public relations element of the marketing mix, communications, has been incorporated in the sales orientation. The need to appeal to their various publics for support caused both profit and nonprofit organizations to communicate a sales message. But the sales technique operated on the assumption that the production tools could function separately. As used in libraries, the sales message simply tried to 
push users to accept what the library wanted to give them on the library's terms. ${ }^{11}$

The marketing orientation, however, uses sales communication as part of a mix with the production tools. This requires planning and evaluation. For instance, fiscal reports would not be put together sporadically on a moment's notice for the purpose of selling the case for increased funding. The procedure would be organized to produce reports on a regular basis in an established, complete format. The planned reports would have more credibility, be easier to interpret, and get better results. Other tasks would not be disrupted, and all concerned would be contributing to a vital part of the library's marketing stratagem.

Marketing in the library can be shown graphically, then, to be composed of four basic units: (1) the production tasks; (2) sales communication; (3) the publics; (4) the marketing dimension (see figure 1). The production tasks are initiated by acquisitions and work toward the distribution of library materials. All of the production tasks feed into the communications commitment. Communications affect all of the library's publics who in turn respond, if all goes well, with continued patronage and support.

In the marketing orientation, all of these activities receive input from planning and evaluation. Planning changes as programs are reassessed. A marketing sentiment without planned programs does not suffice. Kotler warns that "many organizations agree that a major purpose of an organization is to serve customers, but they fail nevertheless to take the necessary organizational steps to implement the marketing concept."

The UMKC Law Library has instituted new materials promotion projects in each of the three communications areas shown in figure 1: display, publication, and fiscal reporting. New books are displayed at a constant location in the circulation area. An acquisitions list is published on a regular basis, and acquisitions expenditures are reported monthly providing a running total of fund allocation unit balances and total balances. Because library publishing is a well-established, dynamic area of promotion, the remainder of this article will focus on that topic. The UMKC Law Library Acquisitions List will serve as an example.

\section{LIBRARY PUBLISHING}

The library field clearly recognizes the value of publishing as a public relations device. Publishing has been called the "long arm of the librarian" penetrating the organization and disseminating policy beyond the library itself. ${ }^{13}$ The very existence of a publication assures the library of recognition:

The library which does not produce a printed or duplicated publication of any kind will not be as well known as one that does, for the library's name alone on the publication must be a reminder of the library's existence, and even the very small publications have a surprising power of penetration within the community. ${ }^{1}$

Some libraries even attempt to use publishing as an income source in itself. Recently it even seems that "virtually every library authority is either publishing or considering the introduction of a publications programme. ${ }^{\prime 15}$ One has only to look in the news sections of the Record or the New Library World to discover the increasing trend towards libraries acting as publishers. ${ }^{16} \mathrm{~A}$ case in point is the Folger Shakespeare Library, which assumed full responsibility for its publications in $1977 .{ }^{17}$

These works tend to publicize single events, such as exhibitions or displays. Sometimes the library's holdings are used as a basis for the work. Often, however, the library's only connection is its publishing role alone. While such activity reveals the movement of libraries toward the commercial sector, it does not demonstrate a marketing technique serving as an extension and communication of production tasks as Kotler has described.

An expedient publication device, an active publicity mechanism providing a systematic announcement of library services, is the acquisitions list/newsletter publication. ${ }^{18}$ It has been used effectively in technical libraries for at least three decades. ${ }^{19}$ Lucille Jackson's study of fifty technical library bulletins in 1952 noted that all were issued at regular intervals, the majority 


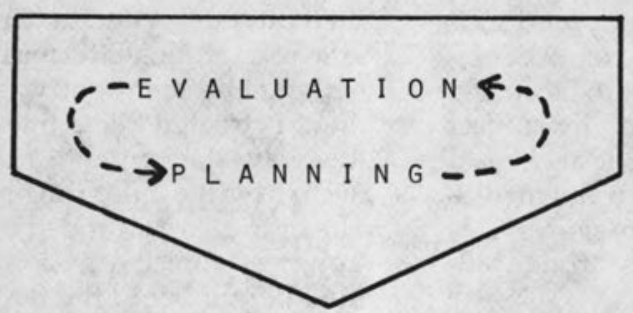

MARKETING

DIMENSION

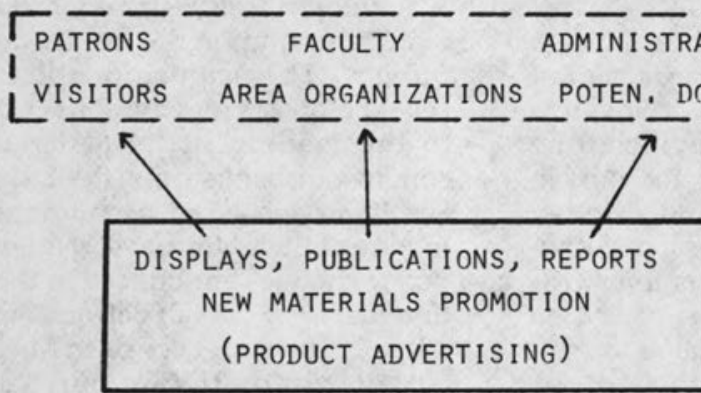

COMMUN I CATIONS

COMMI TMENT

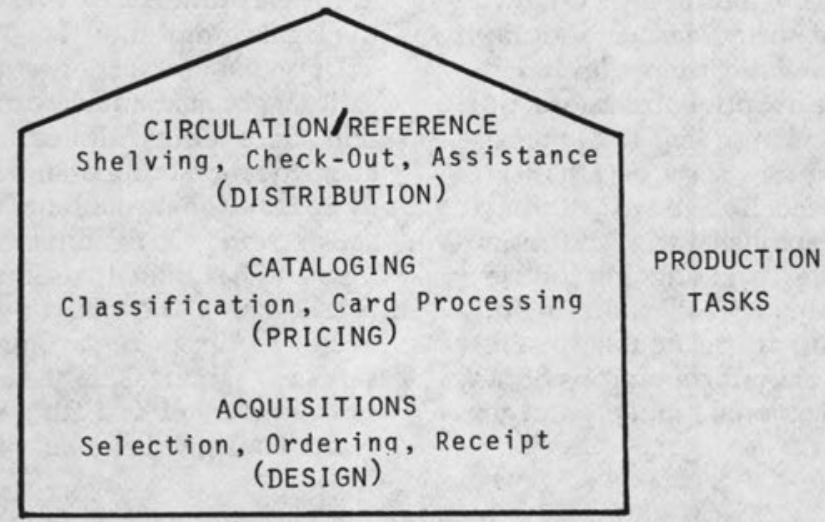

FIGURE 1

Library Marketing Components

being published bimonthly, some monthly, and some weekly. ${ }^{20}$

An overview analysis of these publications reveals that the terms library bulletins, accessions lists, acquisitions lists, information bulletins, book lists, and current awareness bulletins are used interchangeably with only a slight variation of meaning. The term bulletin predominates and almost always includes a review of current periodical literature, usually in a speciallibrary setting. The generic term used is
CA/SDI (current awareness/selective dissemination of information) services. Upto-date information is provided on specific topics. This service has been successful, upon experiment, in both academic and public libraries as well as in special libraries. ${ }^{21}$ Most SDI services are produced manually although automatic, computerized processing of recent accessions has been done successfully. ${ }^{2}$

CA/SDI services, in general, are designed as low-cost publications providing 
current information as quickly and efficiently as possible. A survey of 123 engineering bulletins found most to be bound with one staple and arranged by subject on a standard page size. ${ }^{23}$ Dividing lists of new books into nicely broken down subject headings and putting basic services first and general news later is strongly advised. ${ }^{24}$

\section{THE UMKC LAW LIBRARY ACQUISITIONS LIST}

The UMKC Law Library Acquisitions List began publication in March of 1981. It is distributed to area libraries including eighteen law-firm libraries, four court libraries, two public libraries and six other university law libraries in Missouri, Kansas, and Oklahoma, as well as to UMKC Law School faculty. A copy is placed on display at the public card catalog for students and the general public.

Due to supplemental funding during the 1980-81 fiscal year, the UMKC Law Library was able to increase monograph purchasing from a subsistence level. It became desirable to publicize these purchases to patrons in order to: (1) increase awareness of the new service; (2) assist research needs of faculty and area attorneys; and (3) help establish increased monograph purchasing as an ongoing contribution to the law-library collection. In addition to meeting these goals, the new publication would inform patrons of new policies, organizational changes, and general news items.
To provide a concise, clear, and consistent format, AACR2 format is followed without the main entry line. Each item, then, is treated like a title main entry. In this way, the content of the book, as reflected by the title, catches the eye first. The entries are arranged under Library of Congress subject division headings with the call number to the far left of the page (see figure 2).

The Acquisitions List produced an immediate impact upon the faculty and library publics. The acquisitions librarian received requests for additions and changes to the mailing list. Faculty members sought out books from the List and area law librarians asked for additional information at their attorneys' requests. Major policy changes announced in the publication met with overall patron cooperation. Also, a state budget crisis in Missouri that curtailed subscription purchasing and threatened to eliminate monograph ordering was countered by contributions from the legal community.

These general responses to the List and to library policies indicate that the publication successfully fulfilled its goals. However, the marketing orientation requires a more concrete measurement of consumer satisfaction. ${ }^{25}$ To demonstrate responsiveness and flexibility to user needs, an organization should conduct periodic surveys to get feedback regarding their specific services. ${ }^{26}$ To measure the effectiveness of the Acquisitions List, the acquisitions librarian designed and distributed a survey

LAW OF THE UNITED STATES

KF387

People's law review : an access catalogue to law without

lawyers / edited by Ralph Warner. -- Reading, Mass. :

Addison-Wesley, 1980. -- 「Ready Reference?

KF529 Love pact : a layman's complete guide to legal living

.C57 together agreements / Bernard E. Clair and Anthony R.

Daniele. -- New York : Grove, 1980.

FIGURE 2

Pre-Survey Acquisitions List Entries 
to all recipients of the List (see figure 3).

The main body of the survey addressed the applicability of the Acquisitions List and the clarity of its format. Over half of the respondents reviewed the list totally; 49 percent reviewed it in part. Seventy-eight percent easily located books of interest to them, and 90 percent experienced no diffi- culty interpreting the entries. Of the five ranked categories of usability, 59 percent of the responses fell in the "always" and "frequently" ranges, and 17 percent fell in the "rarely" and "never" area. Fourteen percent of the answers showed occasional usage. Seventy-four percent of the answers to questions three and four re-

\section{GENERAL}

1. Type of Library/Organization:

6 Academic 11 Law Firm 1 Public 2 Court 3 other

2. Survey respondent is:

18 Librarian 4 Faculty 0 Law Firm Attorney 10 ther

3. Estimated book volume count for your Library/Organization is:

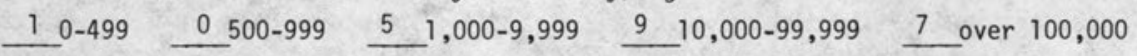

\section{APPLICATION}

1. Upon receipt, the List is:
$\frac{13}{10}$ Reviewed totally
\begin{tabular}{lll}
4 & Routed \& retained \\
\hline 2 & Routed \& discarded
\end{tabular}
2 Posted or displayed
1 Discarded immediately

2. Please rank the List's usefulness to you in the following areas:

\begin{tabular}{l|c|c|c|c|c|c}
\cline { 2 - 6 } & Always & Frequently & Occasionally & Rarely & Never \\
\hline Book Selection Tool & 4 & 6 & 4 & 5 & 1 \\
\hline Borrowing Tool & 3 & 8 & 3 & 3 & 4 \\
\hline Of General Interest & 13 & 2 & 4 & 2 & 1 \\
\hline Filed for Future Reference & 13 & 0 & 1 & 2 & 4 \\
\hline
\end{tabular}

FORMAT

The List is divided according to Library of Congress Classification subject areas using a modified Anglo-American Cataloging Rules II format.

1. Can you locate quickly books of interest to you? 17 yes 2 no

2. Have you experienced any difficulty interpreting the information, i.e., who is the author; who is the publisher? 0 yes 20 no

3. What do you like best about the format? 14 responses

4. What do you like least about the format? 5 responses

\section{RESULTS}

1. Has receiving the List caused you to (check any of the following):
2 Check out more books
4 Visit the library more
4 Order these books
17 Be more aware of recent work in your area

2. How does the List compare to the New Book Display?

$\begin{array}{ll}0 \text { Prefer New Book Display } & 3 \text { Find them equally beneficial } \\ 13 & \text { Prefer Acquisitions List }\end{array}$

(PLEASE STAPLE \& RETURN AT YOUR EARLIEST CONVENIENCE)

FIGURE 3

UMKC Law Library Survey of Acquisitions List Effectiveness 
garding format were positive, and 28 percent requested a format change.

After a marketing-oriented library measures user satisfaction, it must modify its behavior accordingly. ${ }^{27}$ The above summary of results indicates a positive response. In addition, the results section revealed that the List increased library usage slightly and increased user appreciation by 77 percent. The survey, however, did provide a forum for some critical commentary. Question 4 of the format section elicited two major criticisms. The subject headings were considered to be too broad by some respondents, particularly the Law of the United States section. Other respondents expressed a desire for annotated entries to provide content analysis.

As a result of these comments, the Acquisitions List has been revised. The Law of the United States section now is broken down into subcategories according to the KF classification schedule. Annotations are provided when the title seems too broad, when the title might be misleading, or in instances when further description might add interest (see figure 4).

A more serious problem, as revealed by the first section of the survey, was the unbalanced distribution of respondents. Eighteen out of a possible thirty-one librarians responded to the survery, whereas only four of a possible twenty- one faculty members returned the survey. An 83 percent nonresponse level in one group raises the question of a large nonuser population. As evidenced by the experience of the Samuel Chase Law Library, CA/SDI programs directed solely towards law-school faculty can be instituted successfully in cases where "faculty did not see the library's services as anything but peripheral to their teaching and research pursuits. ${ }^{\prime 28} \mathrm{~A}$ communications program directed solely toward faculty members obviously will need to be considered in further planning and evaluation at the UMKC Law Library.

\section{CONCLUSION}

Marketing's role in library practice continues to receive attention at an accelerating rate. A marketing expert in 1980 stated that "marketing and the information professionals have recently 'found' each other. ${ }^{\prime 29}$ In 1982 the American Library Association entitled its Midwinter President's Program, "Marketing: A Key to Surviving and Thriving."

But the growing popularity of the concept has not readily brought forth concrete methodology. As evidenced by commentary at the ALA program, many library systems believe that marketing plans are beyond their reach financially. And indeed, panel speakers seemed to advocate

\title{
LAW OF THE UNITED STATES
}

\author{
LEGAL BIBLIOGRAPHY
}

KF246
Dictionary of current American legal citations : abridged edition with examples / Doris Bieber. -- Buffalo, N. Y. : Hein, 1981. -- [Reserve?

Highly praised for its usability, this

dictionary serves as a companion to the

Harvard "Bluebook" and applies the Bluebook

rules.

FIGURE 4

Post-Survey Acquisitions List Entries 
professional assistance from out of the marketing/business field.

Hopefully, this paper will demonstrate that marketing techniques can emerge as a natural extension of production tasks, feeding into the communications commitment, then to be modified by ongoing planning and evaluation. Even marketing experts themselves can recognize the need for library systems to create their marketing programs themselves:

Marketing talent for the not-for-profit sector is best "home grown." It is far easier for professionals from the government, health, education, and library science sectors to learn what they must about marketing than it is for marketers from the private sector to overcome the many barriers to their becoming effective in a new and strange environment. ${ }^{30}$

\section{REFERENCES}

1. Alberta L. Brown, "Working Smarter with Your Clientele," in Harold S. Sharp, ed., Readings in Special Librarianship (New York: Scarecrow, 1963), p.294.

2. Philip Kotler, Marketing for Nonprofit Organizations (Englewood Cliffs, N.J.: Prentice-Hall, 1975), p.44.

3. Beth M. Gwynn, "Marketing the Law School Library," Law Library Journal 71:234-46 (May 1978).

4. Kotler, Marketing for Nonprofit Organizations, p.45.

5. Ibid., p.xi.

6. Ibid., p.x.

7. Ibid., p. 25

8. Andrea C. Dragon, "Marketing the Library," Wilson Library Bulletin 53:498-502 (March 1979).

9. Kotler, Marketing for Nonprofit Organizations, p.7.

10. Ibid., p.46.

11. Gwynn, "Marketing the Law School Library," p.237.

12. Kotler, Marketing for Nonprofit Organizations, p.46.

13. Nazir Ahmad, "Publicizing Library Resources," Pakistan Library Bulletin 9:21-29 (July-Oct. 1978) as cited in Handbook of Special Librarianship and Information Work (London: Aslib, 1975), p.324.

14. Exhibitionist (pseud.), "Printed Propaganda," Librarian and Book World 49:107-10 (June 1960).

15. Ian Orton, "The Library as Publisher," Assistant Librarian 73:70-73 (May 1980).

16. Roy Field, "The Library as Publisher," Library Association Record 81, no.8:383-85 (Aug. 1979).

17. Publishers' Weekly 212:110 (26 Sept. 1977).

18. John Hall, "Publicity and Promotion for Information Services in University Libraries," Aslib Proceedings 26, no.10:391-95 (Oct. 1974).

19. Lucille Jackson, "Some Observations on Fifty Technical Library Bulletins," Special Libraries 44, no. 9:366-69 (Nov. 1953).

20. Jackson, "Some Observations on Fifty Technical Library Bulletins, p.367.

21. Gwynn, "Marketing the Law School Library," p.242.

22. Moshe Inbal, "Automatic Publishing of Library Bulletins," Special Libraries 71:222-28 (Apr. 1980).

23. Keith G. Blair, "Engineering Library Bulletins: The Human Factors Consideration," in Harold S. Sharp, ed., Readings in Special Librarianship (New York: Scarecrow, 1963), p.367.

24. Phyllis G. Newman, "The Round File Evader," California School Libraries 40:180-81 (May 1969).

25. Kotler, Marketing for Nonprofit Organizations, p.47.

26. Ibid., p.42.

27. Gwynn, "Marketing the Law School Library," p.237.

28. Ibid., p. 241.

29. Stanley J. Shapiro, "Marketing and the Information Professional: Odd Couple or Meaningful Relationship?" Special Libraries 71, no.11:469-74 (Nov. 1980).

30. Ibid., p. 470 . 